\title{
Milligram per Kilogram per Day
}

National Cancer Institute

\section{Source}

National Cancer Institute. Milligram per Kilogram per Day. NCI Thesaurus. Code C66976.

A dose calculation unit expressed in milligram(s) per kilogram per period of time equal to twenty-four hours. 